\title{
Organizational Citizenship Behavior and Performance: The Role of Employee Engagement*
}

\author{
Hermawan HERMAWAN ${ }^{1}$, H.M. THAMRIN² Priyo SUSILO $^{3}$
}

Received: September 10, 2020 Revised: November 08, 2020 Accepted: November 16, 2020

\begin{abstract}
Nowadays, technology and information are developing rapidly. It compels an organization or a company strive to excel in its field. In the Industrial Revolution 4.0 era, companies must maintain their assets and technology to face the competition. One asset that should be paid attention to is human resources. Human resource has two important variables, namely Organizational Citizenship Behavior (OCB) and Employee Engagement (EE). This study aims to analyze the relationship between OCB and EE on Employee Performance (EP) in the manufacturing industry in Tangerang. This study is conducted using a quantitative method with 200 respondents. The data is collected by distributing questionnaires to respondents, which is then analyzed using Structural Equation Modeling (SEM) with AMOS 23 software. The result of this study indicates that OCB has a significant effect on EE and EP. This study also finds that employee engagement has a significant effect on employee performance and can mediate the relationship between OCB and EP. From these results, the implication that can be taken is that the manufacturing industry in Tangerang must pay attention to their employees for them to develop OCB and EE, and eventually increase their performance towards the organization.
\end{abstract}

Keywords: Organizational Citizenship Behavior (OCB), Employee Engagement, Employee Performance

JEL Classification Code: D20, L1, L2, L22

\section{Introduction}

The most important asset in a company is human resources. Humans are assets of the company that cannot be duplicated or imitated by competitors (Anitha, 2014). Employees are the only living assets, so special treatment is needed to maintain loyalty and reduce their desire to

\footnotetext{
*Acknowledgements:

We thank the Ministry of Research, Technology, and Higher Education of Indonesia for providing us with the funding for conducting this research from Thesis Grant scheme 2019/2020.

${ }^{1}$ First Author. Senior Lecturer. Post Graduate Program, Faculty of Economics and Business, Universitas Muhammadiyah Tangerang, Indonesia

${ }^{2}$ Senior Lecturer. Post Graduate Program, Faculty of Economics and Business, Universitas Muhammadiyah Tangerang, Indonesia ${ }^{3}$ Corresponding Author. Senior Lecturer. Post Graduate Program, Faculty of Economics and Business, Universitas Muhammadiyah Tangerang, Indonesia [Postal Address: JI Perintis Kemerdekaan I /33 Cikikol, Tangerang, Indonesia] Email: susilopriyo915@gmail.com

(c) Copyright: The Author(s)

This is an Open Access article distributed under the terms of the Creative Commons Attribution Non-Commercial License (https://creativecommons.org/licenses/by-nc/4.0/) which permits unrestricted non-commercial use, distribution, and reproduction in any medium, provided the unrestricted non-commercial work is properly cited.
origal
}

leave the company voluntarily. Therefore, an organization or company must pay more attention to employees because the company will have better competitiveness if it has good human resources and good employee performance, therefore, the company must be able to see the success of employee performance (Paais \& Pattiruhu, 2020).

Some previous literature found that there are two important variables to improve employee performance, namely Organizational Citizenship Behavior (OCB) (Harwiki, 2016; Muzakki et al. 2019; Bagyo, 2018; Affandi et al. 2018, Lestari, 2018; Hidayah \& Harnoto, 2018; Haerani et al., 2020) and Employee Engagement (EE) (Bedarkar \& Pandita, 2014; Tensay, 2020; Anitha, 2014; Koech \& Cheboi, 2018; Kuruppuge \& Gregar, 2017; Torku \& Dai, 2020). These two variables are important aspects that have been discussed recently by literature and practitioners in improving employee performance.

One of the company's problems in improving the performance of their employees is the formal atmosphere in the company, as it tends to be stiff and less relaxed. These problems can be overcome with OCB (Lestari, 2018). Indirectly, OCB can improve the effectiveness of the organization, therefore OCB is performed without 
restraint by a person (Udin \& Yuniawan, 2020). With OCB, the relationship between employees will be more relaxed, thus the performance and productivity of the employees can be improved. Alkahtani (2015) revealed that OCB has many positive effects for the company such as creating organizational efficiency, the ability to attract and retain capable employees, as well as able to adapt to environmental change.

Another important variable to improve employee performance is EE. More engaged employees will be able to improve their performance and provide good outcomes for the company (Sendawula et al. 2018). EE has a positive attitude and a greater work ethic which is characterized by enthusiasm, dedication, and absorption. This makes employees psychologically loyal to their work and minimizes their mistakes at work.

This study deeply discusses the relationship between Organizational Citizenship Behavior and employee engagement and their effect on employee performance. Previous literature related to OCB and EE mainly discusses companies in the banking industry (Alkahtani, 2015), the hospitality industry (Lyu et al. 2016), education (Runhaar et al., 2013), and service industry (Ariani, 2013; Zhang et al. 2017). This study provides novelty, namely the OCB and EE employee engagement analysis in the manufacturing industry. Besides, this study will also analyze the mediation effect of employee engagement on OCB and employee performance.

\section{Literature Review}

\subsection{Organizational Citizenship Behavior (OCB)}

OCB is defined by Robbins and Judge (2013) as optional behavior that is not a part of an employee's formal work obligations but supports the effective functioning of the organization. Another opinion expressed by Gary (2012) explained that OCB is the voluntary behavior of a worker to do tasks or jobs outside of his or her responsibility or obligation for the advancement or benefit of his organization.

The dimension of OCB which is widely known and used in study is OCB dimension proposed by Organ (2006) which consists of: (1) Altruism, namely the behavior of helping colleagues to complete their work, for example willing to voluntarily help colleagues who not understand and and are new, help colleagues who are overloaded with work, and do the colleague's work who is absent; (2) Courtesy, namely the behavior for problems related to work, for example encouraging colleagues who work lazily; (3) Sportsmanship, which is defined as the behavior of accepting conditions or circumstances that are unpleasant and less ideal, for example, they do not like to complain and ignore reality; (4) Civic virtue, namely responsible behavior to participate in corporate life activities, for example attending meetings that are not necessary for him but beneficial for the company, being willing to follow or obey the changes that occur in the company, having initiative to increase productivity in the company; and (5) Conscientiousness, namely dedication to work and achieve results above the standards set, for example work all day long, not wasting time, obey all company regulations voluntarily, as well as willing to carry out responsibilities that are not a part of their responsibility.

OCB is important for companies because it significantly increases employee engagement (EE) (Alkahtani, 2015; Kataria et al., 2012; Mansoor et al., 2012; Runhaar et al., 2013; Ariani, 2013; Zhang et al., 2017). Previous literature has proven the relationship between OCB and EE in several industries such as the banking industry (Alkahtani, 2015), hospitality industry (Lyu et al. 2016), education (Runhaar et al., 2013), and service industry (Ariani, 2013; Zhang et al., 2017). This study provides novelty, namely the analysis of Organizational Citizenship Behavior and employee engagement in the manufacturing industry.

The relationship between OCB and EE is also proven in the leader-member exchange (LMX) context (Matta et al., 2014). EE will be formed when the company can create an atmosphere that provides work motivation for employees (Mansoor et al. 2012). Besides, Ariani (2013) analyzes differences in OCB practices in males and females. The results of her study found that OCB implemented by males is higher than OCB in females.

Previous studies have also proven that OCB has a significant direct effect on employee performance (Harwiki, 2016; Muzakki et al., 2019; Bagyo, 2018; Affandi et al., 2018, Lestari, 2018; Hidayah \& Harnoto, 2018). Thus, the literature proves that $\mathrm{OCB}$ provides an effective function in the company because it can increase employee engagement and employee performance.

H1: Organizational Citizenship Behavior (OCB) has a significant effect on Employee Engagement $(E E)$.

H2: Organizational Citizenship Behavior (OCB) has a significant effect on Employee Performance (EP).

\subsection{Employee Engagement (EE)}

Employee engagement (EE) is a condition when employees are enthusiastic, passionate, energetic, and committed to their work (Maylett \& Warner, 2014). According to Marciano (2010), employee engagement is the extent to which a person is committed, dedicates himself, and loyal to the organization, superiors, work, and 
colleagues. The concept of engagement refers to individual involvement and job satisfaction which has the same level as work enthusiasm.

Schiemann (2011) argues that EE is a condition when an employee does three things, namely attracts positive feelings about the company, predicts important employee behaviors such as high wise behavior, and exceeds the lowest limit, which results in higher performance or adaptive behavior such as problem-solving and creative decision. These adaptive behaviors can be influenced by the company's actions, especially the supervisor. In other words, engaged employees have a physical, cognitive, and emotional connection with their work roles (Albrecht, 2010).

EE has three key drivers, namely communication, worklife balance, and leadership (Bedarkar \& Pandita, 2014). Further, EE has several other determinants namely work environment, leadership, team and co-workers, training and career development, compensation, organizational policies, and workplace well-being (Anitha, 2014). The importance of EE encourages many researchers to examine more deeply the determinants and effects of $\mathrm{EE}$ on other variables in the company. According to Rub and Fawzi (2004), the measurement of EE consists of teamwork, pleasant working conditions, treatment of employees, growth opportunities, flexible working practices, and good leadership and management practices.

Previous literature has suggested the essential role of EE. One of which is EE can improve employee performance (Bedarkar \& Pandita, 2014; Tensay, 2020; Anitha, 2014; Koech \& Cheboi, 2018; Kuruppuge \& Gregar, 2017; Torku $\&$ Dai, 2020). EE is a concept that has a significant role in an organization and has been widely discussed in different literature in the last ten years. As a result, it is common that some companies use engaged employees as business strategy partners (Bedarkar \& Pandita, 2014).

Humans are one of the factors that cannot be duplicated or imitated by competitors and are recognized as the company's most valuable asset if they are managed properly. Engagement, in this matter, can become a solution to create quality human resources and improve employee performance. Besides, EE can also mediate other variables, one of which is the OCB on employee performance. Bagyo (2018) found the ability of EE to mediate the relationship between OCB and employee performance.

H3: Employee engagement (EE) has a significant effect on Employee Performance (EP).

H4: Employee engagement (EE) significantly mediates the relationship between Organizational Citizenship Behavior $(O C B)$ and employee performance.

\subsection{Employee Performance (EP)}

EP is a financial or non-financial outcome of an employee who has a relationship or direct effect on company performance (Anitha, 2014). EP is an individual thing because each employee has different abilities. EP depends on the level of skills and abilities, effort, and opportunities they have (Bagyo, 2018).

Some previous literature found that improving EP requires EE (Bedarkar \& Pandita, 2014; Tensay, 2020; Anitha, 2014; Koech \& Cheboi, 2018; Kuruppuge \& Gregar, 2017; Torku \& Dai, 2020) and OCB (Harwiki, 2016; Muzakki et al. 2019; Bagyo, 2018; Affandi et al., 2018, Lestari, 2018; Hidayah \& Harnoto, 2018). This is because the employee who is engaged will develop positive feelings toward their company, which will eventually result in improved performance. These two aspects are important variables for the company and have been studied in the last 10 years.

According to Robbins and Judge (2013), performance measurement consists of several indicators including quality, quantity, accuracy, effectiveness, and independence. Quality is the level at which the outcome is close to perfect in adjusting ideal ways of performing activities or fulfilling the expected goals. Quantity is the amount produced expressed in the number of units or activity cycles completed. Accuracy is the coordination angle time with the output results and maximizing the time available for other activities.

Furthermore, effectiveness is the level of organizational resources to increase profits or reduce losses from each unit when using the resources. Independence is the level at which an employee conducts his work function without asking for help and guidance from the supervisor to avoid adverse results (Robbins \& Judge, 2013).

\section{Research Methods}

This study is conducted using a quantitative method with Structural Equation Modeling (SEM). The population of this study is employees in the manufacturing industry in Tangerang. The manufacturing industry is one of the largest labor absorbers in Tangerang, Indonesia. It is interesting to analyze because it is expected to represent the majority of Tangerang people. From this population, a sample of 200 respondents is taken. The data in this study is obtained by distributing questionnaires to each of the respondents, which is then analyzed using AMOS 23 software.

This study analyzes 3 variables including one exogenous variable, namely $\mathrm{OCB}$, and two endogenous variables, namely EE and employee performance. The variables and indicators in this study are described in Table 1. 
Table 1: Variable Measurements

\begin{tabular}{|c|c|c|}
\hline Variable & Indicator & Item \\
\hline \multirow{5}{*}{$\begin{array}{l}\text { Organizational } \\
\text { Citizenship } \\
\text { Behaviour (OCB) } \\
\text { (Organ,2006) }\end{array}$} & $\begin{array}{l}\text { Altruism } \\
\text { (The nature of being concerned with } \\
\text { the interests of the other) }\end{array}$ & $\begin{array}{l}\text { 1. Help other people's assignments when they are the } \\
\text { absence }\end{array}$ \\
\hline & $\begin{array}{l}\text { Civic Virtue } \\
\text { (Support the organizational functions) }\end{array}$ & 2. Support cooperation and decisions of the team \\
\hline & $\begin{array}{l}\text { Conscientious } \\
\text { (Behavior that exceeds the minimum } \\
\text { prerequisites) }\end{array}$ & 3. Willing to work extra time \\
\hline & $\begin{array}{l}\text { Courtesy } \\
\text { (Behavior of being kind \& respect } \\
\text { others) }\end{array}$ & 4. Supportive behavior among colleagues \\
\hline & $\begin{array}{l}\text { Sportsmanship } \\
\text { (Behavior that emphasizes the } \\
\text { positive aspects of the organization) }\end{array}$ & 5. Give a positive effect on inside and outside environment \\
\hline \multirow{6}{*}{$\begin{array}{l}\text { Employee } \\
\text { Engagement (EE) } \\
\text { (Rub \& Fawzi, 2004) }\end{array}$} & Team Work & 1. Contribution in the organization \\
\hline & Pleasant Working Condition & 2. Adequate facilities and equipment \\
\hline & The treatment of employees & 3. Appreciation from the company \\
\hline & $\begin{array}{l}\text { Growth Opportunities } \\
\text { (Opportunity to develop) }\end{array}$ & 4. Jobs which provide hope for future needs \\
\hline & Flexible Working Practice & 5. Time availability to take annual paid leave \\
\hline & $\begin{array}{l}\text { Good Leadership and Management } \\
\text { Practice }\end{array}$ & 6. Good commitment from management leadership \\
\hline \multirow{5}{*}{$\begin{array}{l}\text { Employee } \\
\text { performance } \\
\text { (Robbins \& Judge, } \\
\text { 2013) }\end{array}$} & Quality of work & 1. Work with full of calculating, meticulous, and scrupulous \\
\hline & Quantity of work & $\begin{array}{l}\text { 2. Work quantity in accordance with the work standards } \\
\text { expected by the company }\end{array}$ \\
\hline & Accuracy & 3. Work completion in accordance with the planned time \\
\hline & Effectiveness & $\begin{array}{l}\text { 4. Ability to determine and manage work priorities } \\
\text { effectively }\end{array}$ \\
\hline & Independency & $\begin{array}{l}\text { 5. Properly work execution without any guidance or } \\
\text { direction from the head department or their respective } \\
\text { superiors }\end{array}$ \\
\hline
\end{tabular}

\section{Results}

\subsection{Respondents' Characteristics}

Respondents' characteristics in this study are explained in several criteria, including gender, age, education, and income. The majority of the respondents is male $(52.2 \%)$, the age is in the range of $41-50$ years old $(34.5 \%)$, the latest education is mostly in high school (56\%), and most of the respondents have worked or working in the manufacturing industry for about 2-6 years (44.5\%). A detailed explanation of the respondents' characteristics can be seen in Table 2 .

\subsection{Normality Test and Outlier}

The normality test is used to determine whether the data is normally distributed or not. In the normality test, data is normal if the multivariate $\mathrm{CR}$ value is in the range $+/-2.58$. The result of the normality test can be seen in Table 3:

Table 3 shows that the multivariate CR value is 2.475 , which is still in the $+/-2.58$ range, so the data in this study has been normally distributed. Meanwhile, the outlier test is conducted by the Mahalanobis Distance as a benchmark. The data has no outliers if the value of the Mahalanobis distance does not exceed the Chi-square value. In this study, the Chisquare value with a degree of freedom of 16 indicators at 
Table 2: Respondents' Characteristics

\begin{tabular}{|c|c|c|}
\hline Description & Frequency & Percentage \\
\hline \multicolumn{3}{|l|}{ Gender } \\
\hline Male & 95 & $47,5 \%$ \\
\hline Female & 105 & $52,5 \%$ \\
\hline \multicolumn{3}{|l|}{ Age } \\
\hline 20-30 years old & 34 & 17 \\
\hline $31-40$ years old & 65 & 32,5 \\
\hline $41-50$ years old & 69 & 34,5 \\
\hline$<50$ years old & 32 & 16 \\
\hline \multicolumn{3}{|l|}{ Education } \\
\hline High School & 112 & 56 \\
\hline Diploma & 39 & 19,5 \\
\hline Bachelor degree & 34 & 17 \\
\hline Master degree & 15 & 7,5 \\
\hline \multicolumn{3}{|l|}{ Length of work } \\
\hline$>1$ years & 33 & 16,5 \\
\hline 2-6 years & 89 & 44,5 \\
\hline$<7$ years & 78 & 39 \\
\hline Total Respondent & & $100 \%$ \\
\hline
\end{tabular}

Table 3: Normality Test

\begin{tabular}{|c|c|c|c|c|c|c|}
\hline Variable & Min & Max & skew & c.r. & Kurtosis & c.r. \\
\hline EE6 & 2,000 & 5,000 &,- 637 & $-3,678$ & ,054 & , 156 \\
\hline OC5 & 2,000 & 5,000 &,- 876 & $-5,058$ & ,206 & ,596 \\
\hline OC4 & 2,000 & 5,000 &,- 758 & $-4,376$ &,- 063 &,- 181 \\
\hline OC3 & 2,000 & 5,000 &,- 566 & $-3,265$ &,- 144 &,- 415 \\
\hline OC2 & 2,000 & 5,000 &,- 802 & $-4,629$ & ,349 & 1,006 \\
\hline OC1 & 2,000 & 5,000 &,- 691 & $-3,990$ & ,076 & ,221 \\
\hline EE5 & 2,000 & 5,000 &,- 768 & $-4,436$ & ,258 & ,745 \\
\hline EE4 & 2,000 & 5,000 &,- 696 & $-4,019$ & ,125 & ,360 \\
\hline EE3 & 2,000 & 5,000 &,- 566 & $-3,268$ & ,098 & ,282 \\
\hline EE2 & 2,000 & 5,000 &,- 668 & $-3,857$ & ,069 & , 199 \\
\hline EE1 & 2,000 & 5,000 &,- 677 & $-3,907$ & ,345 & ,996 \\
\hline EP1 & 2,000 & 5,000 &,- 961 & $-5,549$ &, 093 & ,267 \\
\hline EP2 & 2,000 & 5,000 &,- 790 & $-4,561$ & ,183 &, 529 \\
\hline EP3 & 2,000 & 5,000 &,- 815 & $-4,706$ & ,220 & ,635 \\
\hline EP4 & 2,000 & 5,000 &,- 725 & $-4,187$ &,- 075 &,- 216 \\
\hline EP5 & 2,000 & 5,000 &,- 494 & $-2,849$ &,- 400 & $-1,155$ \\
\hline Multivariate & & & & & 8,399 & 2,475 \\
\hline
\end{tabular}


the $\mathrm{p}$ level of $<0.001$ is 32 . The results of the outlier test show that the highest Mahalanobis distance value is 31.917. Therefore, the value does not exceed the Chi-square value, which is 32 , thus it can be concluded that the data do not contain outliers.

\subsection{Validity Test}

The validity test shows the questions on the questionnaire reveal something that is measured by the questionnaire. Validity measurement is conducted by looking at the loading factor value. According to Hair et al. (2010), the minimum number of factor loading is $\geq 0.5$, or ideally, $\geq 0.7$ is said to be valid. Based on the loading factor value obtained from the test results, all indicators in this study have a loading factor value above 0.5 . Therefore, all indicators are valid.

\subsection{Reliability Test}

A reliability test is used to measure whether the constructs in this study are reliable or not. Good reliability is when the value of construct reliability is $>0.7$ and the value of the variance extracted is $>0.5$. From the calculation results, the construct reliability of all variables has shown a value $\geq 0.7$. Each variable of the variance extracted has a value of $\geq 0.5$. Therefore, it can be concluded that the questionnaire used for this study is reliable.

\subsection{Goodness of Fit}

The confirmatory model suitability test is tested using the Goodness of Fit Index. Hair et al. (1998) divided the
GOFI (Goodness of Fit Index) criteria into 3 types, namely absolute fit indices, incremental fit indices, and parsimony fit indices. In this study, several criteria are taken from each type of GOFI, namely CMINDF and RMSEA representing absolute fit indices, CFI and TLI representing incremental fit indices, and PGFI and PNFI representing parsimony fit indices. The results of the confirmatory analysis can be seen in Table 4.

Table 4 shows that all the criteria for the goodness of fit have fulfilled the standard, therefore, the model in this study fulfilled the goodness of fit standard.

\subsection{Hypothesis Test}

The next analysis is a full model Structural Equation Model (SEM) analysis to test the hypotheses developed in this study. The results of the regression weight test can be seen in Figure 1 and Table 5.

Critical Ratio (CR) value and the probability $(\mathrm{P})$ value of the data processing results can be seen to decide whether the hypothesis is accepted or rejected. If the test results show a CR value above 1.96 and a probability value (P) below 0.05 / $5 \%$, the proposed study hypothesis is accepted. In this study, 5 hypotheses are proposed, as follows:

H1: Organizational Citizenship Behavior (OCB) has a significant effect on Employee Engagement (EE)

Based on data processing, it is known that the $C R$ value is 8.366 and the $P$ value is 0.000 . These results indicate that the CR value is above 1.96 and the $P$ value is below 0.05 . Therefore, it can be concluded that Organizational Citizenship Behavior (OCB) has a significant effect on Employee Engagement (EE). Therefore, H1 is supported.

Table 4: Goodness of Fit

\begin{tabular}{|l|c|c|c|c|}
\hline Fit Index & Goodness of Fit & Criteria & Cut-off value & Description \\
\hline \multirow{2}{*}{ Absolute Fit } & RMSEA & $\leq 0.08$ & 0,055 & Fit \\
\cline { 2 - 4 } & GFI & $\geq 0.90$ & 0,902 & Fit \\
\hline \multirow{2}{*}{ Incremental Fit } & TLI & $\geq 0.90$ & 0,965 & Fit \\
\cline { 2 - 4 } & CFI & $\geq 0.90$ & 0,971 & Fit \\
\hline \multirow{2}{*}{ Parsimony Fit } & PGFI & $\geq 0.60$ & 0,656 & Fit \\
\cline { 2 - 4 } & PNFI & $\geq 0.60$ & 0,765 & Fit \\
\hline
\end{tabular}

Table 5: Regression Weight

\begin{tabular}{|l|c|c|c|c|c|c|}
\hline \multicolumn{2}{|c|}{ Relationship between variables } & Estimate & S.E. & C.R. & P \\
\hline EE & $<---$ & OCB & 1,177 &, 141 & 8,366 &, 000 \\
\hline EP & $<---$ & OCB &, 590 &, 287 & 2,055 &, 040 \\
\hline EP & $<---$ & EE &, 524 &, 254 & 2,061 &, 039 \\
\hline
\end{tabular}




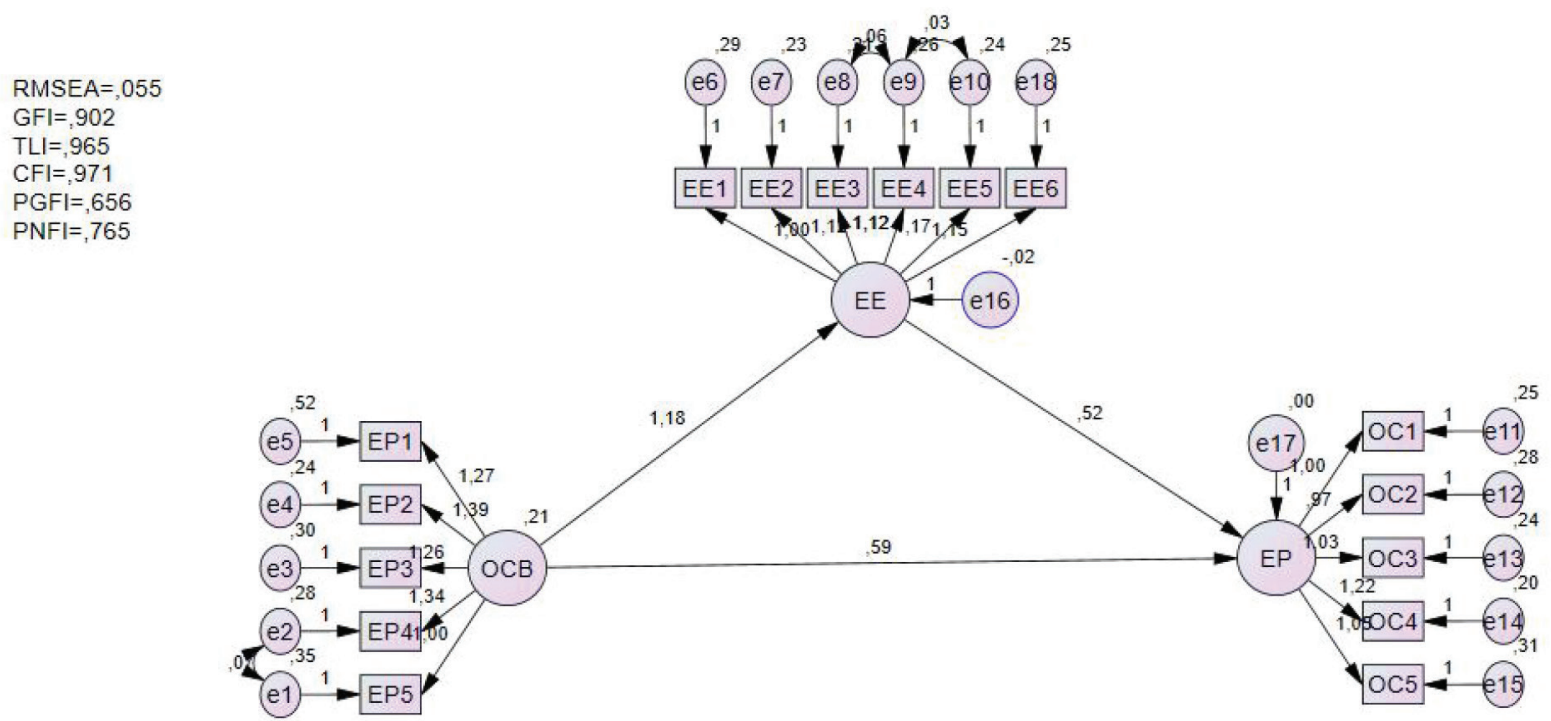

Figure 1: Path Analysis

Table 6: Mediation Test Results

\begin{tabular}{|c|c|}
\hline & P-Value \\
\hline OCB - EE - EP & 0,014 \\
\hline
\end{tabular}

H2: Organizational Citizenship Behavior (OCB) has a significant effect on Employee Performance (EP)

Based on data processing, it is known that the CR value is 2.055 and the $P$ value is 0.040 . These results indicate that the $\mathrm{CR}$ value is above 1.96 and the $\mathrm{P}$ value is below 0.05 . Therefore, it can be concluded that the Organizational Citizenship Behavior (OCB) has a significant effect on Employee Performance (EP). Therefore, H2 is supported.

H3: Employee Engagement (EE) has a significant effect on Employee Performance (EP)

Based on data processing, it is known that the $C R$ value is 2.061 and the $\mathrm{P}$ value is 0.039 . These results indicate that the CR value is above 1.96 and the $\mathrm{P}$ value is below 0.05 . Therefore, it can be concluded that Employee Engagement (EE) has a significant effect on Employee Performance (EP). Therefore, H3 is supported.

\subsection{Mediation Testing}

Mediation testing is seen from the significance of the indirect effect between variables from the table the indirect effect-two tailed significance. The results of the indirect effect analysis are as shown in Table 6:

Based on the mediation test in Table 6, it is known that:
H4. Employee Engagement (EE) significantly mediates the relationship between Organizational Citizenship Behavior (OCB) and Employee Performance.

Table 6 shows that the relationship between Organizational Citizenship Behavior (OCB) and Employee Performance (EP) mediated by Employee Engagement (EE) has a significance value of 0.014 . These results indicate that Employee Engagement (EE) significantly mediates the effect of Organizational Citizenship Behavior (OCB) on Employee Performance (EP). Therefore, H4 is supported.

\section{Discussion}

The most effective business strategy in increasing productivity is to produce quality human resources. Human resource is the most important asset for the company; therefore the company must work hard to improve its quality and performance. This study proposes an increase in employee performance (EP) through Organizational Citizenship Behavior (OCB) and employee engagement (EE). This study also analyzed the mediating role of EE on OCB and EP.

The results of this study state that OCB has a significant effect on EE. It supports previous studies conducted by Alkahtani (2015), Kataria et al. (2012), Mansoor et al. (2012), Runhaar et al. (2013), Ariani, (2013), and Zhang et al. (2017). The results of the statistical analysis also find that OCB has a significant effect on EP and also supports previous studies by Harwiki (2016), Muzakki et al. (2019), Bagyo (2018); Affandi et al. (2018), Lestari (2018), and Hidayah and Harnoto (2018). 
This study proposes four aspects in the OCB that can improve EE and EP, namely Altruism (The nature of being concerned with the interests of the other), Civic Virtue (Support the organizational functions, Conscientious (behavior that exceeds the minimum prerequisites), Courtesy (Behavior of being kind \& respect others) and Sportsmanship (Behavior that emphasizes the positive aspects of the organization). Good implementation of these aspects can increase EE and EP.

This study analysis also finds the relationship between employee engagement and employee performance. EE is proven to have a significant effect on EP which supports previous studies conducted by Bedarkar and Pandita (2014), Tensay (2020), Anitha (2014), Koech and Cheboi (2018), Kuruppuge and Gregar (2017), and Torku and Dai (2020). EE also significantly mediates the relationship between OCB and EP

Companies, mainly in the field of the manufacturing industry need to focus on several aspects, such as Team Work, Pleasant Working Conditions, Growth Opportunities, Flexible Working Practice, Good Leadership, and Management Practice to implement EE.

Thus, this study proposes an EP development concept that is supported by two variables, namely the OCB and EE. Manufacturing companies in Tangerang are expected to pay more attention to employees and create an environment that can motivate employees, therefore will create OCB and EE among employees. When employees have developed OCB and $\mathrm{EE}$, their performance toward the organization will also increase.

\section{Conclusion}

This study emphasizes the importance of employees as company assets which have a big role in business strategy. From the statistical analysis results, there are 4 findings to improve employee performance, namely:

1. Organizational Citizenship Behavior (OCB) has a significant effect on Employee Engagement (EE)

2. Organizational Citizenship Behavior (OCB) has a significant effect on Employee Performance (EP)

3. Employee Engagement (EE) has a significant effect on Employee Performance (EP)

4. Employee engagement significantly mediates the relationship between Organizational Citizenship Behavior (OCB) and Employee Performance (EP)

\section{References}

Affandi, A. S., Patrisia, D., Syahrizal., A. (2018). The effect of employee engagement and job satisfaction on Organizational Citizenship Behavior (OCB). Advances in Economics, Business and Management Research, 64, 807-815.
Albrecht, S. (2010). Handbook of employee engagement: Perspectives, issues. research and practice. London, UK: Edward Elgar Publishing

Alkahtani, A. (2015). Organizational Citizenship Behavior (OCB) and rewards. International Business Research, 8(4), 210-222.

Anitha. (2014). Determinants of employee engagement and their impact on employee performance. International Journal of Productivity and Performance Management, 63(3), 308-323. https://doi.org/10.1108/IJPPM-01-2013-0008/full/html

Ariani, D.W.(2013). The relationship between employee engagement, organizational citizenship behavior, and counterproductive work behavior. International Journal of Business Administration, 4(2), 46-56. https://doi.org/10.5430/ijba.v4n2p46

Bagyo, Y. (2018). The effect of Counterproductive Work Behavior (CWB) and Organizational Citizenship Behavior (OCB) on employee performance with employee engagement as an intervening variable. IOSR Journal of Business and Management. 20(2), 83-89.

Bedarkar, M., \& Pandita, D. (2013). A study on the drivers of employee engagement impacting employee performance. Social and Behavioral Sciences, 133, 106-115. https://doi. org/10.1016/j.sbspro.2014.04.174

Gary, Y. (2012). Leadership in the organization. Upper Saddle, NJ: Prentice-Hall, Inc

Haerani, S., Sumardi, S., Hakim, W., Hartini, H., \& Putra, A. H. P. K. (2020). Structural model of developing human resources performance: Empirical study of Indonesia states owned enterprises. Journal of Asian Finance, Economics, and Business, 7(3), 211-221. https://doi.org/10.13106/jafeb.2020. vol7.no3.211

Harwiki, W. (2016). The impact of servant leadership on organization culture, organizational commitment, Organizational Citizenship Behaviour (OCB), and employee performance in women cooperatives. Social and Behavioral Sciences. 219, 283-290. https://doi.org/10.1016/j.sbspro.2016.04.032

Hidayah, S., \& Harnoto, H. (2018). Role of Organizational Citizenship Behavior (OCB), perception of justice, and job satisfaction on employee performance. Jurnal Dinamika Manajemen, 9(2), 170-178.

Kataria, A., Garg, P., \& Rastogi, R. (2012). Employee engagement and organizational effectiveness: The role of organizational citizenship behavior. International Journal of Business Insights \& Transformation, 6(1), 102-113.

Koech, C. J., \& Cheboi, J. (2018). An empirical analysis of employee engagement on employee performance in technical institutions in Kenya. International Journal of Advances in Management and Economics, 7(1), 36-46.

Kuruppuge, R. H., \& Gregar, A. (2017). Family involvement, employee engagement, and employee performance in enterprising family firms. Acta Universitatis Agriculturae et Silviculturae Mendelianae Brunensis, 65(5), 1695-1707.

Lestari, T. W. (2018). Organizational Citizenship Behavior (OCB), variable on employees of PT. Smartfren Jember. International Journal of Social Science and Business, 2(4), 231-236. 
Lyu, Y., Zhu, H., Zhong, H., \& Hu, L. (2016). Abusive supervision and customer-oriented organizational citizenship behavior: The roles of hostile attribution bias and work engagement. International Journal of Hospitality Management. 53, 69-80. https://doi.org/10.1016/j.ijhm.2015.12.001

Mansoor, N., Aslam, H. D., Javad, T., Ashraf, F., \& Shabbir, F. (2012). Exploring Organizational Citizenship Behavior (OCB) and its critical link to employee engagement for effectual human resource management in organizations. Mediterranean Journal of Social Sciences. 3(1), 567-576.

Marciano, P. L. (2010). Carrots and sticks don't work: Build a culture of employee engagement with the principles of respect. New York, NY: McGraw Hill.

Matta, F. K., Scott, B. A., Koopman, J., \& Conlon, D. E. (2014). Does seeing "eye to eye" effect work engagement and OCB? A role theory perspective on LMX Agreement. Academy of Management Journal. 58(6), 1686-1708. https://doi. org/10.5465/amj.2014.0106

Maylett, T., \& Warner, P. (2014). Magic: Five keys to unlock the power of employee engagement. Austin, TX: Greenleaf Book Group.

Muzakki, M., Eliyana, A., \& Muhtadi, R. (2019). Is employee performance affected by organizational culture, work motivation, and Organizational Citizenship Behavior (OCB)?: An Empirical Investigation. International Journal of Integrated Education, Engineering, and Business. 1(1), 36-42. https://doi. org/10.29138/ijieeb.v2i1.810

Organ, D. W. (2006). Organizational citizenship behavior: The good soldier syndrome. Lexington, MA: Lexington Books.

Paais, M., \& Pattiruhu, J. R. (2020). Effect of motivation, leadership, and organizational culture on satisfaction and employee performance. Journal of Asian Finance, Economics, and Business, 7(8), 577-588. https://doi.org/10.13106/jafeb.2020.vol7.no8.577

Robbins, S. P., Judge, T. A., \& Vohra, N. (2013). Organizational behavior (15th ed). India: Pearson Education Services Pvt Ltd
Rub A. A. \& Fawzi, R. (2004). Job stress, job performance, and social support among hospital nurses. Journal of Nursing Scholarship, 36(1), 73-78. https://doi.org/10.1111/j.15475069.2004.04016.x

Runhaar, P., Judith, K., \& Sanders, K. (2013). Teachers' organizational citizenship behavior: Considering the roles of their work engagement, autonomy, and leader-member exchange. Teaching and Teacher Education. 30, 99-108. https:// doi.org/10.1016/j.tate.2012.10.008

Sendawula, K., Kimuli, S. N., Bananuka, J., \& Mugangga, G. N. (2018). Training, employee engagement, and employee performance: Evidence from Uganda's health sector. Cogent Business \& Management, 5(1), 1-12. https://doi.org/10.1080/2 3311975.2018.1470891

Tensay, A. T., \& Singh, M. (2020). The nexus between HRM, employee engagement, and organizational performance of federal public service organizations in Ethiopia. Heliyon, 6(6), 1-14. https://doi.org/10.1016/j.heliyon.2020.e04094

Torku, B., \& Dai, B. (2020). Influence of transformational leadership on work engagement and employee performance. International Journal of Scientific Research in Computer Science, Engineering and Information Technology, 6(1), 62-73. https;//doi.org/10.1257/aer.99.1.544

Udin, N., \& Yuniawan, A. (2020). Psychological capital, personality traits of big-five, Organizational Citizenship Behavior (OCB), and task performance: Testing their relationships. Journal of Asian Finance, Economics, and Business, 7(9), 781-790. https://doi.org/10.13106/ jafeb2020vol7.no9.781

Zhang, Y., Guo Y., \& Newman, A. (2017). Identity judgments, work engagement, and organizational citizenship behavior: The mediating effects based on the group engagement model. Tourism Management. 61, 190-197. https://doi.org/10.1016/j. tourman.2017.01.005 